\title{
ANALYSIS OF THE MANAGE DRAIN CONCENTRATION DATABASE TO EVALUATE AGRICULTURAL MANAGEMENT EFFECTS ON DRAINAGE WATER NUTRIENT CONCENTRATIONS
}

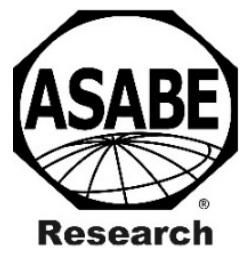

\author{
A. Hertzberger, C. M. Pittelkow, R. D. Harmel, L. E. Christianson
}

\begin{abstract}
Agricultural systems are substantial contributors of nonpoint-source nitrogen $(N)$ and phosphorus $(P)$ pollution, and loss of dissolved forms of these nutrients is exacerbated in subsurface-drained (tile-drained) landscapes. The majority of reviews summarizing drainage nutrient losses have focused on $N$ and $P$ loads, but closer inspection of drainage concentrations is necessary to more directly link cropping management factors with water quality outcomes. More than 1,500 recently compiled site-years of drainage $N$ and $P$ concentration in the Measured Annual loads from AGricultural Environments (MANAGE) Drain Concentration database were used to analyze the impacts of crop selelction, nutrient management, and tillage type on annual drainage nutrient concentrations. The highest annual flow-weighted mean $\mathrm{NO}_{3}-\mathrm{N}$ concentrations across the database were from corn, corn and soybean (grown within the same plot in the same year), and soybean site-years (14.0, 13.5, and $12.1 \mathrm{mg} \mathrm{L}^{-1}$, respectively). However, crop selection was not a significant predictor for annual average dissolved reactive phosphorus (DRP) concentrations in drainage. Nitrogen application rates below $75 \mathrm{~kg}$ ha $a^{-1}$ for corn did not significantly reduce annual $\mathrm{NO}_{3}-\mathrm{N}$ concentrations compared to rates of 75 to $149 \mathrm{~kg} \mathrm{ha} a^{-1}$ or 150 to

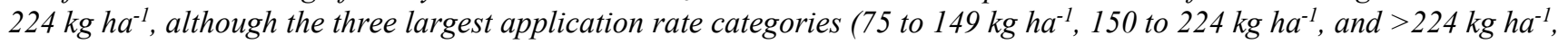
respectively) resulted in significantly increasing $\mathrm{NO}_{3}-\mathrm{N}$ concentrations. The stepwise regression approach was used to reduce and select predictors to model annual $\mathrm{NO}_{3}-\mathrm{N}$ and DRP concentrations. Regression analysis of $\mathrm{NO}_{3}-\mathrm{N}$ concentrations had an overall model $R^{2}$ of $0.59(n=254)$ and indicated that $N$ application rate had the greatest effect on $N_{3}-N$ concentrations in corn site-years, followed by fertilizer timing and tillage type. Regression analysis of DRP concentrations had an overall $R^{2}$ of 0.94, and although the model was less robust due to the small sample size $(n=47)$, fertilizer timing was most closely correlated with annual DRP concentrations. The MANAGE database will continue to evolve and remain a resource for new exploratory efforts to better understand and reduce nutrient losses from agricultural systems.
\end{abstract}

Keywords. Concentration, Drainage, Nitrogen, Phosphorus, Water quality.

$\mathrm{N}$ utrient-related water quality impairments continue to increase due, in part, to contributions from the agricultural sector (Diaz and Rosenberg, 2008; Galloway et al., 2003). Excess nitrogen $(\mathrm{N})$ in waters is responsible for eutrophication and hy-

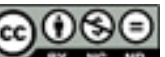

The authors have paid for open access for this article. This work is licensed under a Creative Commons Attribution-NonCommercial-NoDerivatives 4.0 International License https://creativecommons.org/licenses/by-nc-nd/4.0/

Submitted for peer review in November 2018 as manuscript number NRES 13230; approved for publication as a Research Article by the Natural Resources \& Environmental Systems Community of ASABE in May 2019.

Mention of company or trade names is for description only and does not imply endorsement by the USDA. The USDA is an equal opportunity provider and employer.

The authors are Allan Hertzberger, Graduate Student, and Cameron Pittelkow, Assistant Professor, Department of Crop Sciences, University of Illinois, Urbana, Illinois; R. Daren Harmel, Director, USDA-ARS Center for Agricultural Resources Research, Fort Collins, Colorado; Laura Christianson, Assistant Professor, Department of Crop Sciences, University of Illinois, Urbana, Illinois. Corresponding author: Laura Christianson, AW-101 Turner Hall, 1102 South Goodwin Ave., Urbana, IL 61801; phone: 217-244-6173; e-mail: lechris@illinois.edu. poxia in coastal regions (Galloway et al., 2003), while phosphorus $(\mathrm{P})$ is generally the limiting reactant in freshwater eutrophication (Schindler et al., 2008). Movement of these two nutrients in agroecosystems is complex due to numerous pathways that vary with changes in agricultural management practices, topography, soils, and climate. Loss of dissolved forms of these nutrients is exacerbated in subsurface-drained (tile-drained) landscapes, where drain pipes generally reduce overland flow but create a new pathway for $\mathrm{NO}_{3}-\mathrm{N}$ and dissolved P transport (Ball Coelho et al., 2012; King et al., 2015). In the Midwestern U.S., subsurface drainage systems have improved the production of annual crops, primarily corn (Zea mays L.) and soybean (Glycine max [L.] Merr.) (Gentry et al., 2009). A combination of highly productive soils, heavy $\mathrm{N}$ and $\mathrm{P}$ inputs, and artificial drainage have resulted in this region contributing significant nutrient loads to the hypoxic zone in the Gulf of Mexico. A better understanding of the major factors influencing subsurface drainage nutrient transport is needed to mitigate the negative water quality impacts of this type of agricultural system.

The majority of reviews summarizing drainage nutrient losses have focused on $\mathrm{N}$ and $\mathrm{P}$ loads, which are a function 
of both nutrient concentration and discharge, but closer inspection of drainage concentrations is necessary to more directly link management factors with water quality outcomes. Source, timing, placement, and rate of $\mathrm{N}$ and $\mathrm{P}$ inputs are important controllable management criteria for keeping nutrients in the vadose zone, where they can be used by plants, and minimizing the susceptibility for losses to the environment. The 4R Nutrient Stewardship approach is focused on applying the right fertilizer source at the right rate at the right time and place to aid in these efforts to reduce eutrophication and hypoxia while maintaining profitability for the farmer (Fertilizer Institute, 2015). These types of efforts are particularly important in landscapes with subsurface drainage, where losses of dissolved forms of $\mathrm{N}$ and $\mathrm{P}$ are exacerbated by the artificially modified hydrology. Due to the diversity of climate, crops, and management practices used across North America, much work is needed to determine the relationships between specific $4 \mathrm{R}$ fertilizer management practices and drainage nutrient concentrations reported in the peer-reviewed literature. While increasing momentum behind 4R nutrient stewardship for production agriculture in North America could hold promise for improving water quality outcomes, an analysis of the variability of nutrient concentrations across different agricultural contexts is a critical step in developing evidence-based management strategies (Eagle et al., 2017a).

The MANAGE database was created to give a broad perspective of nutrient losses from agricultural and forested landscapes (Harmel et al., 2006, 2008), with recent database additions incorporating agricultural drainage nutrient losses (Christianson and Harmel, 2015a; Harmel et al., 2016, 2017). The MANAGE Drain Concentration component (Hertzberger et al., 2019) recently compiled subsurface and surface drainage nutrient concentrations to bolster past MANAGE studies evaluating the link between agricultural management practices and drainage $\mathrm{N}$ and $\mathrm{P}$ losses (Christianson and Harmel, 2015a, 2015b; Christianson et al., 2016). It is important to determine how management practices affect total drainage nutrient loads as well as the impact of management practices on drainage nutrient concentrations, because concentration values are important criteria for water quality impairment. For instance, Lawlor et al. (2008) found no significant difference in annual $\mathrm{NO}_{3}-\mathrm{N}$ loads when compared across $\mathrm{N}$ application rates in a corn-soybean rotation, but they observed significantly higher annual $\mathrm{NO}_{3}-\mathrm{N}$ concentrations at higher application rates compared to lower rates. The objective of this study was to use the newly compiled MANAGE Drain Concentration database to assess the effects of important North American agricultural management decisions (e.g., crop selection, 4R nutrient management, and tillage) on $\mathrm{NO}_{3}-\mathrm{N}$ and dissolved reactive phosphorus (DRP) concentrations in subsurface drainage.

\section{MATERIALS AND Methods}

More than 1500 site-years (a site-year refers to one year of a specific treatment at a single location) of drainage $\mathrm{N}$ and $\mathrm{P}$ concentration data from 79 peer-reviewed studies were recently compiled into the MANAGE Drain Concentration database. Previously described by Hertzberger et al. (2019), this database was created from a literature review performed between May and December 2016, and all the literature siteyears that were included consisted of field observation data from the U.S. or Canada, contained at least one full year of data, included a drainage area of at least 0.009 ha, were considered "free drainage", and were not from a rain simulation or lysimeter study. The corresponding location, cropping system, nutrient application, soil properties, management practices, precipitation, and drainage information was recorded for each site-year when reported in the original publications. Concentrations reported as annual values in the original publications were sourced into the MANAGE database as such, although roughly one-third of the database siteyears reflected a data collection period that was not a full year due to the nature of drainage research in many locations (e.g., sampling stopped in the fall or winter due to cessation of drainage or frozen conditions). When the sample collection period was explicitly stated in the original study, the site-year generally corresponded with a calendar year (e.g., $<15 \%$ of database site-years followed the water year or a fall start date). While the database contained more than 1500 site-years in total, not all site-years contained both $\mathrm{N}$ and $\mathrm{P}$ concentrations. A variety of $\mathrm{N}$ and $\mathrm{P}$ species of water quality concern were included in the database (Hertzberger et al., 2019), but only $\mathrm{NO}_{3}-\mathrm{N}$ and DRP concentrations and only subsurface drainage site-years (i.e., excluding surface and ditch drainage site-years) were included in the present analysis. Detailed precipitation event information (e.g., intensity, duration, frequency) was often not reported in the original studies used to compile the MANAGE database; thus, these types of information were not available for analysis here.

The compiled drainage nutrient concentrations and associated cropping management factors (fertilization, tillage, etc.) were then analyzed statistically. Analyses of crop type versus $\mathrm{NO}_{3}-\mathrm{N}$ and DRP concentrations were performed by differentiating annual arithmetic mean concentrations from annual flow-weighted mean concentrations and comparing both cropping types and averaging methods using an approximate t-test $(\alpha=0.05)$, which uses an approximate t-distribution and approximate standard errors to account for nonnormality and heterogeneous variances. All fertilizer analyses were performed using only corn site-years, corn being the most prevalent crop in the database. For analysis of $\mathrm{N}$ rate effects as a $4 \mathrm{R}$ management component, data were grouped into four $\mathrm{N}$ application rate categories based on practical metric breakpoints that encompassed commonly used application rates in corn cropping systems research: 0 to $74 \mathrm{~kg} \mathrm{ha}^{-1}$ (including non-fertilized plots), 75 to $149 \mathrm{~kg}$ $\mathrm{ha}^{-1}, 150$ to $224 \mathrm{~kg} \mathrm{ha}^{-1}$, and $>224 \mathrm{~kg} \mathrm{ha}^{-1}$. Nutrient application timings were classified as out of season ( $>2$ months before planting, generally in fall or winter), pre-plant ( 2 months to one week before planting, generally early spring), at-plant (within one week of planting), and side dress ( $>1$ week after planting), consistent with previous nutrient management studies performed with MANAGE data (Christianson et al., 2016). Nutrient application methods were classified as incorporated, injected, or surface applied. Within MANAGE, up to two unique nutrient application formulations, timings, and/or placements could be reported for 
any given site-year. For site-years where two $\mathrm{N}$ application timings and/or methods were reported, the timing and method used for the analyses was the one that corresponded to more than $50 \%$ of the total reported application rate in that site-year. Studies reporting nutrient applications of manure or other organic sources (litter) either directly reported the application rate in terms of $\mathrm{N}$ and/or $\mathrm{P}$ or reported the manure application rate and the manure nutrient content, from which the nutrient application rate was calculated. For nutrient application-related analyses, assessment of flowweighted $\mathrm{NO}_{3}-\mathrm{N}$ concentrations was restricted to site-years where $\mathrm{N}$ or $\mathrm{N}+\mathrm{P}$ applications occurred. To assess flowweighted DRP concentrations, site-years with only N+P applications were used (no corn site-years with only $\mathrm{P}$ applications were reported). Analysis of tillage data included all site-years reporting tillage type, annual precipitation, annual drainage discharge, and annual flow-weighted concentrations of either $\mathrm{NO}_{3}-\mathrm{N}$ or DRP. Tillage types assessed were conventional tillage (leaving $<15 \%$ residue cover, including moldboard plowing and disc tilling with a second pass with a field cultivator), conservation tillage (leaving $>30 \%$ residue cover, including chisel plow and ridge tillage), and notill. Annual arithmetic mean values were excluded from all analyses other than the cropping and stepwise regression analyses due to the small sample sizes and/or large variances. Most data did not meet normality and homogeneity of variance assumptions and thus were analyzed using the Proc Glimmix procedure in SAS (ver. 9.4). The N application rate and split-N datasets, which fulfilled the assumption of normality but not homogeneity of variances, were analyzed using the Proc Mixed procedure.

Models for flow-weighted $\mathrm{NO}_{3}-\mathrm{N}$ and DRP concentrations in corn site-years were created using stepwise regression as an exploratory approach, employing both forward and backward addition and elimination of terms, to identify factors across the database that most likely have the greatest influence on subsurface drainage concentrations. Stepwise data sets met assumptions of normality and constant variance. Twenty-nine first-order and second-order variables reasonably known to impact drainage nutrient concentrations, including two-way interactions, were used in the stepwise approach and deemed fixed effects: tillage, fertilizer method of application, fertilizer timing, split N, N application rate, annual precipitation, annual drain discharge, drain discharge/precipitation, and quadratic nitrogen application rate (N App2). Variables were eliminated using $\alpha=0.50$ due to few powerful predictors and many irrelevant predictors, and a combination of $\mathrm{R}^{2}$ values and Akaike's corrected information criterion (AICC) were used due to the ratio of observations to estimable predictors to select the best overall model (Harrell, 2015; Burnham and Anderson, 2002). Observations were drawn randomly from the database to account for any within-study variance, and residual plots showed that the data were normally distributed with constant variance. Classifications for the regression of annual $\mathrm{NO}_{3}-\mathrm{N}$ concentration were as follows: fertilizer timings were binned into before planting (including out of season and pre-plant applications) and otherwise (at-plant and side dress applications), tillage practices were binned into conventional and otherwise (no-till and conservation), and fertilizer methods were binned into injected and otherwise (incorporated and surface applied). Classifications for the regression of annual DRP concentrations included binning fertilizer timings into before planting (included out of season and pre-plant applications) and otherwise, and binning fertilizer methods into surface applied and otherwise (incorporated and injected). Classifications were binned based on similarity of practices (e.g., no-till and conservation tillage reduce soil disturbance compared to conventional tillage; out of season and pre-plant applications occur before planting compared to at-plant and side dress applications) or to isolate a more common practice in the database (i.e., injected $\mathrm{N}$ fertilizer compared to incorporated or surface applied).

Results discussed here are compared to individual works found within the MANAGE Drain Concentration database to provide examples of maintained effects of management practices across this much larger analysis.

\section{RESULTS AND DISCUSSION \\ CROPPING SYSTEMS}

The highest annual flow-weighted mean $\mathrm{NO}_{3}-\mathrm{N}$ concentrations compiled in the MANAGE Drain Concentration database were from corn $\left(14.0 \mathrm{mg} \mathrm{L}^{-1}\right)$, corn and soybean grown within the same plot (13.5 $\mathrm{mg} \mathrm{L}^{-1}$; e.g., Helmers et al., 2012; Hoover et al., 2015), and soybean (12.1 $\mathrm{mg} \mathrm{L}^{-1}$; fig. 1). These $\mathrm{NO}_{3}-\mathrm{N}$ concentrations were not significantly higher than alfalfa (Medicago sativa L.; $8.2 \mathrm{mg} \mathrm{L}^{-1}$ ) but were significantly higher than grass $\left(2.3 \mathrm{mg} \mathrm{L}^{-1}\right)$, which was defined in the database as prairie, pasture, grass mixture, permanent grass cover, and Conservation Reserve Program (CRP). Annual arithmetic mean $\mathrm{NO}_{3}-\mathrm{N}$ concentrations followed a similar trend, with corn (14.8 $\left.\mathrm{mg} \mathrm{L}^{-1}\right)$ and soybean $(14.3 \mathrm{mg}$ $\left.\mathrm{L}^{-1}\right)$ having significantly higher annual arithmetic mean concentrations than alfalfa $\left(1.8 \mathrm{mg} \mathrm{L}^{-1}\right)$ and grass $\left(2.0 \mathrm{mg} \mathrm{L}^{-1}\right)$ (fig. 1). The averages for annual crop site-years were greater than $10 \mathrm{mg} \mathrm{L}^{-1}$, which is the USEPA-established maximum contaminant level (MCL) for $\mathrm{NO}_{3}-\mathrm{N}$ in drinking water, while the averages for perennial site-years were lower (USEPA, 2009). Perennials such as alfalfa and grasses have an active root system that supports $\mathrm{N}$ uptake and recycling for longer periods of the year, while also requiring lower or no $\mathrm{N}$ and $\mathrm{P}$ fertilizer inputs compared to annual crops. Bolton et al. (1970) found that the greatest $\mathrm{N}$ concentrations and loads came from fields growing corn, whether continuously cropped or in rotation, compared to bluegrass, oats, and alfalfa. More recently, Daigh et al. (2015) found, in all years of their experiment, that flow-weighted $\mathrm{NO}_{3}-\mathrm{N}$ concentrations in both fertilized and unfertilized prairie systems ranged from 2 to 195 times lower than in continuous corn and corn-soybean rotations. It is well established that $\mathrm{NO}_{3}$ $\mathrm{N}$ losses in subsurface drainage from annual cropping systems can be greater than $\mathrm{NO}_{3}-\mathrm{N}$ drainage losses from perennial cropping systems (Randall et al., 1997; Tomer and Liebman, 2014), and these results further demonstrate this.

Flow-weighted versus arithmetic $\mathrm{NO}_{3}-\mathrm{N}$ means for a given crop were not significantly different from each other for any crop (e.g., flow-weighted versus arithmetic means for corn were 14.0 versus $14.8 \mathrm{mg} \mathrm{L}^{-1}$ ). However, arithmetic 


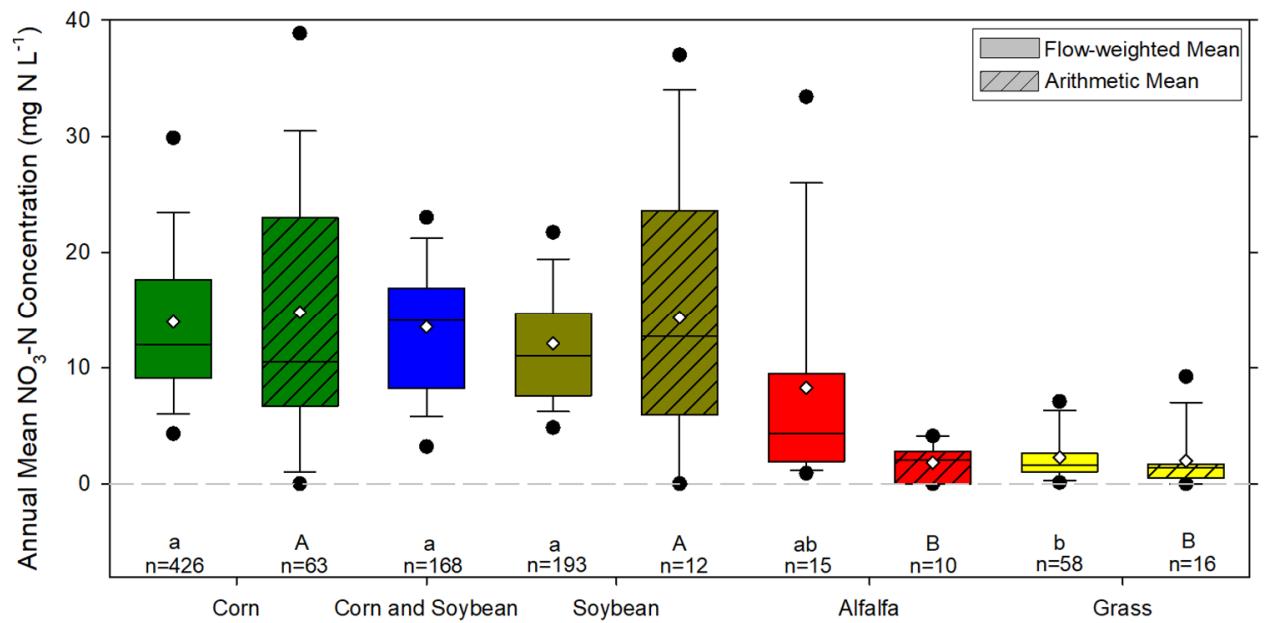

Figure 1. Annual flow-weighted mean and arithmetic mean $\mathrm{NO}_{3}$-N concentrations by crop type compared across the $\mathrm{MANAGE}$ Drain Concentration database. There were no arithmetic mean "corn and soybean" site-years. Lowercase and uppercase letters represent statistical analysis for flow-weighted and arithmetic concentrations, respectively. Boxes with the same letter for a given averaging type are not significantly different at $\alpha=0.05$ (e.g., comparing flow-weighted concentrations for corn versus soybean versus alfalfa, etc.). Boxes, stems, and dots represent the 25 th and 75 th, 10th and 90th, and 5th and 95th percentiles, respectively; the horizontal line is the median concentration, and the diamond is the mean concentration. There were no significant differences between averaging methods for any given crop type (e.g., comparing flow-weighted versus arithmetic concentrations for corn).

mean annual $\mathrm{NO}_{3}-\mathrm{N}$ concentration distributions for corn and soybean had noticeably wider ranges than their flowweighted counterparts. This may suggest that sample collec-tion methods that do not support flow-weighting may not be as precise as the methods used in flowweighted calculations, or this could be related to the relatively smaller sample sizes for the arithmetic means reported in the database (e.g., flow-weighted versus arithmetic $\mathrm{NO}_{3}-\mathrm{N}$ site-years for soybean were 193 versus 12). Annual mean $\mathrm{NO}_{3}-\mathrm{N}$ concentrations were more variable (had larger distributions) for annual cropping systems than for perennial cropping systems, although this was slightly confounded by the relatively smaller sample sizes of perennials in the database (fig. 1).

Annual flow-weighted DRP concentrations for corn, soybean, and alfalfa site-years compiled in the MANAGE Drain Concentration database were not significantly different, with means of $0.20,0.27$, and $0.15 \mathrm{mg} \mathrm{L}^{-1}$, respectively (fig. 2). This finding indicates that cropping system was a relatively less important factor for the movement of DRP to subsurface drainage systems compared to $\mathrm{NO}_{3}-\mathrm{N}$. Likewise, Daigh et al. (2015) found no difference in flowweighted total reactive $P$ concentrations among continuous corn, corn-soybean rotation, and both fertilized and unfertilized prairie systems. There were no significant differences between flow-weighted and arithmetic DRP means for a given crop across the database (e.g., flow-weighted versus arithmetic means for corn were 0.20 versus $0.16 \mathrm{mg} \mathrm{P} \mathrm{L}^{-}$ $\left.{ }^{1} ; \alpha=0.05\right)$.

\section{NUTRIENT MANAGEMENT Nutrient Rate}

Nitrogen application rates were "binned" to represent realistic breakpoints used in corn cropping systems research. The distribution of $\mathrm{N}$ application rates compiled across the database varied by application category, with the 0 to $74 \mathrm{~kg}$ $\mathrm{ha}^{-1}$ category having the widest range and the $>224 \mathrm{~kg} \mathrm{ha}^{-1}$

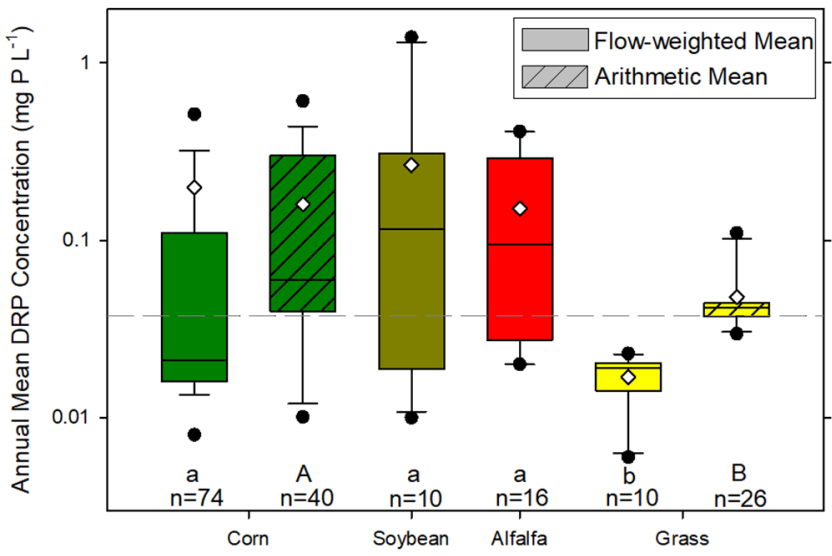

Figure 2. Annual flow-weighted mean and arithmetic mean DRP concentrations by crop type compared across the MANAGE Drain Concentration database (log-scale $y$-axis). Lowercase and uppercase letters represent statistical analysis for flow-weighted and arithmetic concentrations, respectively. Boxes with the same letter for a given averaging type are not significantly different at $\alpha=0.05$ (e.g., comparing flowweighted concentrations for corn versus soybean versus alfalfa, etc.). Boxes, stems, and dots represent the 25th and 75th, 10th and 90th, and 5th and 95th percentiles, respectively; the horizontal line is the median concentration, and the diamond is the mean concentration. There were no significant differences between averaging methods for any given crop type (e.g., comparing flow-weighted versus arithmetic concentrations for corn).

category having the narrowest range (fig. 3a). Higher N application rates generally produced larger annual flowweighted $\mathrm{NO}_{3}-\mathrm{N}$ concentrations, with the 0 to $74 \mathrm{~kg} \mathrm{ha}^{-1}, 75$ to $149 \mathrm{~kg} \mathrm{ha}^{-1}, 150$ to $224 \mathrm{~kg} \mathrm{ha}^{-1}$, and $>224 \mathrm{~kg} \mathrm{ha}^{-1}$ application categories resulting in mean annual flow-weighted $\mathrm{NO}_{3}$ $\mathrm{N}$ concentrations of $13.6,12.0,14.4$, and $19.2 \mathrm{mg} \mathrm{L}^{-1}$, respectively (fig. 3b). Similar findings were documented in Iowa, with Helmers et al. (2012) reporting an increase in N application rate to corn contributing to higher $\mathrm{NO}_{3}-\mathrm{N}$ concentrations in subsurface drainage (the $\mathrm{N}$ application rates in that study were 0 to $168 \mathrm{~kg} \mathrm{~N} \mathrm{ha}^{-1}$ in $56 \mathrm{~kg} \mathrm{~N} \mathrm{ha}^{-1}$ increments 


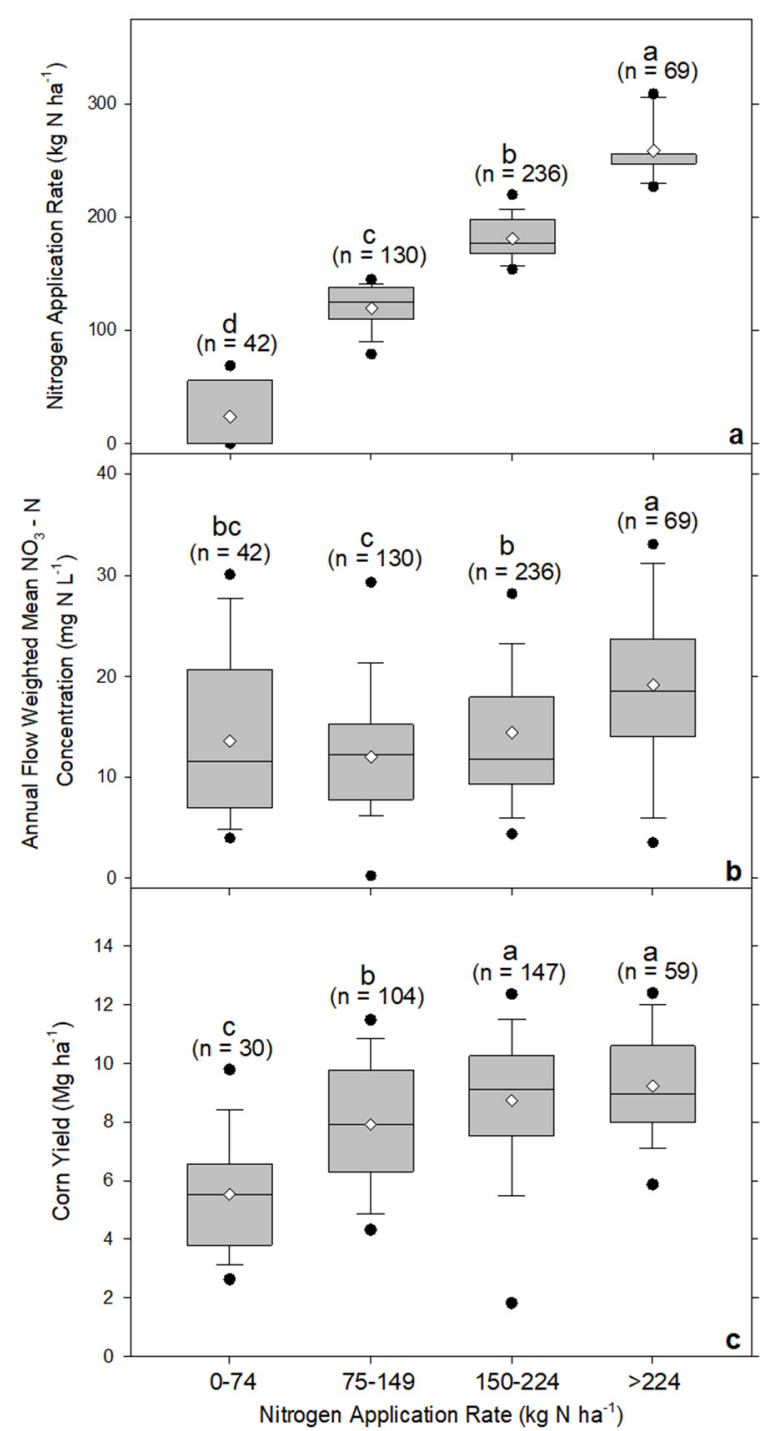

Figure 3. (a) Mean $\mathrm{N}$ application rates $\left(\mathrm{kg} \mathrm{ha}^{-1}\right)$, (b) annual flowweighted mean $\mathrm{NO}_{3}-\mathrm{N}$ concentrations $\left(\mathrm{mg} \mathrm{L}^{-1}\right)$, (c) and corn yields $\left(\mathrm{Mg} \mathrm{ha}^{-1}\right)$ for the four $\mathrm{N}$ application categories using corn site-years only. Means with the same letter are not significantly different $(\alpha=$ 0.05). Boxes, stems, and dots represent the 25th and 75th, 10th and 90th, and 5th and 95th percentiles, respectively; the horizontal line is the median concentration, and the diamond is the mean concentration.

for corn after soybean and 0 to $224 \mathrm{~kg} \mathrm{~N} \mathrm{ha}^{-1}$ in $56 \mathrm{~kg} \mathrm{~N}$ $\mathrm{ha}^{-1}$ increments for corn after corn). Lawlor et al. (2011) found reductions in subsurface $\mathrm{NO}_{3}-\mathrm{N}$ concentrations with reduced $\mathrm{N}$ application rates applied at the same time regard- less of fertilizer source over a four-year period (spring application $252 \mathrm{~kg} \mathrm{ha}^{-1}$ aqua-ammonia $>$ spring $218 \mathrm{~kg} \mathrm{ha}^{-1}$ manure $>$ spring $168 \mathrm{~kg} \mathrm{ha}^{-1}$ aqua-ammonia). While the three highest $\mathrm{N}$ application categories exhibited significant increasing flow-weighted concentrations, only the highest application category was significantly higher than the 0 to $74 \mathrm{~kg} \mathrm{ha}^{-1}$ category (including non-fertilized control plots in the database), which had relatively high median and mean values $\left(>10 \mathrm{mg} \mathrm{L}^{-1}\right)$. These results highlight the important point that a low $\mathrm{N}$ application rate does not necessarily equate with improved water quality.

Increasing the $\mathrm{N}$ application rate to between 150 and $224 \mathrm{~kg} \mathrm{ha}^{-1}$ (a typical range for Midwestern corn) increased the corn yield, and additional $\mathrm{N}$ above that range did not increase yields (fig. 3c). As generally observed, yields plateaued at high $\mathrm{N}$ rates, and the application categories of 150 to $224 \mathrm{~kg} \mathrm{ha}^{-1}$ and $>224 \mathrm{~kg} \mathrm{ha}^{-1}$ were not significantly different, with means of 8.7 and $9.2 \mathrm{Mg} \mathrm{ha}^{-1}$, respectively. Similar results have been noted in literature, with Helmers et al. (2012) reporting no difference in continuous corn yields at $\mathrm{N}$ application rates of $168 \mathrm{~kg} \mathrm{ha}^{-1}$ compared to $224 \mathrm{~kg} \mathrm{ha}^{-1}$. A recent meta-analysis of corn site-years across the U.S. found an "expected saturating response curve" across a wide range of $\mathrm{N}$ application rates, although the shape and magnitude of the curve varied by location (Eagle et al., 2017b). Similar to recent work (McLellan et al., 2018), an integrated interpretation of these data across $\mathrm{N}$ rates, drainage $\mathrm{N}$ concentrations, and corn yields (i.e., figs. $3 \mathrm{a}, 3 \mathrm{~b}$, and $3 \mathrm{c}$ ) reinforces the concept that $\mathrm{N}$ rates that exceed the requirement for optimal crop yields can lead to greater $\mathrm{N}$ losses.

\section{Nutrient Timing}

For the fertilizer timing analysis, flow-weighted $\mathrm{NO}_{3}-\mathrm{N}$ concentrations were examined when a given site-year reported either N-only applications or a combined $\mathrm{N}$ and $\mathrm{P}$ source. Dissolved P concentrations were compiled for analysis of fertilizer timing only when a site-year reported a combined $\mathrm{N}+\mathrm{P}$ nutrient application. In other words, there were no corn site-years with $\mathrm{P}$ application only. Out of season and pre-plant fertilizer timings showed significantly greater corn yields (10.2 and $9.6 \mathrm{Mg} \mathrm{ha}^{-1}$, respectively) compared to side dress and at-plant timings (8.1 and $6.8 \mathrm{Mg} \mathrm{ha}^{-1}$, respectively) (table 1). This was also the case for annual flow-weighted $\mathrm{NO}_{3}-\mathrm{N}$ concentrations, with out of season and pre-plant concentration means of 15.8 and $15.7 \mathrm{mg} \mathrm{L}^{-1}$, respectively, and side dress and at-plant concentrations of 13.1 and $12.0 \mathrm{mg}$ $\mathrm{L}^{-1}$, respectively (table 1 ). The higher $\mathrm{NO}_{3}-\mathrm{N}$ concentrations corresponded with $\mathrm{N}$ application timings that were furthest

Table 1. Corn yields $\left(\mathrm{Mg} \mathrm{ha}^{-1}\right)$, mean $\mathrm{N}$ and $\mathrm{P}$ application rates $\left(\mathrm{kg} \mathrm{ha}^{-1}\right)$, and flow-weighted mean $\mathrm{NO}_{3}-\mathrm{N}$ and $\mathrm{DRP}$ concentrations $\left(\mathrm{mg}^{-1}\right)$ associated with fertilizer application timing categories in the MANAGE Drain Concentration database. Numbers in parentheses are sample size. Sample sizes are associated with fertilizer application timings, and data between columns may not be associated with the same studies. Within a column, means with the same letter are not significantly different $(\alpha=0.05)$.

\begin{tabular}{|c|c|c|c|c|c|}
\hline Fertilizer Application Timing & $\begin{array}{c}\text { Corn Yield } \\
\left(\mathrm{Mg} \mathrm{ha}^{-1}\right)\end{array}$ & $\begin{array}{c}\text { N Application } \\
\text { Rate } \\
\left(\mathrm{kg} \mathrm{N} \mathrm{ha}^{-1}\right)\end{array}$ & $\begin{array}{c}\mathrm{NO}_{3}-\mathrm{N} \\
\text { Concentration }{ }^{[\mathrm{a}]} \\
\left(\mathrm{mg} \mathrm{L}^{-1}\right) \\
\end{array}$ & $\begin{array}{c}\text { P Application } \\
\text { Rate } \\
\left(\mathrm{kg} \mathrm{P} \mathrm{ha}^{-1}\right) \\
\end{array}$ & $\begin{array}{c}\text { DRP } \\
\text { Concentration }^{[\mathrm{b}} \\
\left(\mathrm{mg} \mathrm{L}^{-1}\right)\end{array}$ \\
\hline Out of season, $>2$ months before planting & $10.2(51) \mathrm{a}$ & $177(80) b$ & $15.8(94) \mathrm{a}$ & $60(10) a$ & $0.09(10) \mathrm{c}$ \\
\hline Pre-plant, 2 months to 1 week before planting & $9.6(108) \mathrm{a}$ & 192 (174) a & $15.7(183) \mathrm{a}$ & $34(26) b$ & $0.19(30) \mathrm{b}$ \\
\hline At-plant, within 1 week of planting & $6.8(64) \mathrm{c}$ & $140(66) \mathrm{c}$ & $12.0(66) b$ & $65(4) \mathrm{a}$ & $0.45(4) \mathrm{a}$ \\
\hline Side/top dress, $>1$ week after planting & $8.1(99) \mathrm{b}$ & $165(130) \mathrm{b}$ & $13.1(130) \mathrm{b}$ & $\mathrm{N} / \mathrm{A}(0)^{[\mathrm{c}]}$ & $\mathrm{N} / \mathrm{A}(0)^{[\mathrm{c}]}$ \\
\hline
\end{tabular}

[a] Data from $\mathrm{N}$ or $\mathrm{N}+\mathrm{P}$ nutrient sources.

[b] Data from N+P nutrient sources only.

[c] No data available. 
from the seasonal crop demand. Likewise, Mitchell et al. (2000) reported that pre-plant $\mathrm{N}$ applications resulted in significantly greater $\mathrm{NO}_{3}-\mathrm{N}$ concentrations in subsurface drainage water compared to side dress applications, and Gentry et al. (1998) observed greater drainage $\mathrm{NO}_{3}-\mathrm{N}$ concentrations from fall versus spring applied $\mathrm{N}$ in corn cropping systems in Illinois. However, Lawlor et al. (2011) found no difference in leached $\mathrm{NO}_{3}-\mathrm{N}$ concentrations between fall and spring applied $\mathrm{N}$ regardless of fertilizer source. In the present study, the $\mathrm{N}$ application rates were significantly greater for pre-plant treatment compared to the other treatments; thus, the timing analysis was confounded with the $\mathrm{N}$ rate. Contrasting results in the literature regarding the impact of $\mathrm{N}$ application timing on drainage $\mathrm{N}$ concentrations and the confounding effects observed in this study between $\mathrm{N}$ application timing and $\mathrm{N}$ rate highlight recent calls for additional coordinated field research on this subject (Eagle et al., 2017a). At-plant timing of $\mathrm{N}$ and $\mathrm{P}$ combined sources showed a significantly higher annual flow-weighted DRP concentration $\left(0.45 \mathrm{mg} \mathrm{L}^{-1}\right)$ than out of season and pre-plant timings ( 0.09 and $0.19 \mathrm{mg} \mathrm{L}^{-1}$, respectively), but this difference was likely due to the extremely small sample size of reported at-plant site-years, four of which were all sourced from the same research site (Zhang et al., 2015); therefore, these results should not be generalized (table 1). Concentrations of DRP may have also been confounded by pre-fertilization soil test $P$ values, which were largely unknown due to a lack of reporting (e.g., only approximately $20 \%$ of database site-years reported soil test $P$ ).

Across the MANAGE Drain Concentration database, annual flow-weighted mean $\mathrm{NO}_{3}-\mathrm{N}$ concentrations from siteyears with split-N applications were not significantly different from non-split application site-years (13.7 versus $12.7 \mathrm{mg} \mathrm{N} \mathrm{L}^{-1}$, respectively; $\mathrm{p}=0.205$; data not shown). These results suggest that split-N applications are not essential for reducing $\mathrm{NO}_{3}-\mathrm{N}$ leaching. Similarly, Jaynes and Colvin (2006) found consistent $\mathrm{NO}_{3}-\mathrm{N}$ concentrations above $10 \mathrm{mg} \mathrm{L}^{-1}$ for three different rates of $\mathrm{N}$ applied at post-emergence and for another treatment of split post-emergence $\mathrm{N}$ application (post-emergence coupled with midseason applications) in corn. In addition, Kanwar et al. (1988) found significantly higher $\mathrm{NO}_{3}-\mathrm{N}$ concentrations from a split-N application at $125 \mathrm{~kg} \mathrm{ha}^{-1}$ than from a single $\mathrm{N}$ application at $175 \mathrm{~kg} \mathrm{ha}^{-1}$ under a no-till system.

\section{Nutrient Placement}

Incorporation of $\mathrm{N}$ and/or $\mathrm{P}$ resulted in the highest corn yield (11.2 $\left.\mathrm{Mg} \mathrm{ha}^{-1}\right)$ compared to injected and surface applied methods (8.3 and $4.8 \mathrm{Mg} \mathrm{ha}^{-1}$, respectively), despite $\mathrm{N}$ and $\mathrm{P}$ application rates that were not significantly different between application methods (table 2). Vetsch and Randall (2000) found that injecting urea ammonium nitrate (UAN) at the V1/V2 growth stages increased corn yield in both continuous corn and corn-soybean rotations, as compared to preplant broadcast UAN. Likewise, Mengel et al. (1982) reported that injected anhydrous ammonia and UAN resulted in greater corn yield than surface applied UAN and urea. However, in the present study, incorporation and injection of $\mathrm{N}$ resulted in significantly greater $\mathrm{NO}_{3}-\mathrm{N}$ concentrations than surface application (table 2), which may have been due to the confounding effect of application timing. Injected and incorporated fertilizer applications tend to occur out of season and pre-plant, while surface application is most often done in season, either at-plant or as a side dress application. Indeed, of the 31 surface application site-years with reported $\mathrm{NO}_{3}-\mathrm{N}$ concentrations and fertilizer timing (table 2), $74 \%$ were applied at-plant or within-season (14 site-years had side dress application, and nine site-years had at-plant application). Moreover, 39 of 54 incorporated site-years and 161 of 290 injected site-years that reported fertilizer timing ( $72 \%$ and $56 \%$, respectively) applied $\mathrm{N}$ fertilizer in fall or early spring (i.e., either as out of season or pre-plant for incorporated and injected site-years). Investigating further into this $\mathrm{N}$ application method $\times$ timing interaction revealed that the mean annual $\mathrm{NO}_{3}-\mathrm{N}$ concentration for injected fertilization before planting (out of season and pre-plant; $16.2 \mathrm{mg} \mathrm{L}^{-1}, n=$ 161) was significantly higher than for injected fertilizer applied in-season (at-plant and side dress; $12.6 \mathrm{mg} \mathrm{L}^{-1}, n=129$ ) (data not shown), supporting the results from the fertilizer timing analysis (table 1). The mean annual flow-weighted $\mathrm{NO}_{3}-\mathrm{N}$ concentration for surface applied fertilizers at side dress (15.2 $\left.\mathrm{mg} \mathrm{L}^{-1}, n=24\right)$ was significantly higher than that of non-side dress site-years (the mean for out of season, preplant, and at-plant was $6.3 \mathrm{mg} \mathrm{L}^{-1}, n=39$ ). While this is not in agreement with the general recommendation that side dress $\mathrm{N}$ application can help reduce $\mathrm{N}$ loss in drainage water, this analysis did not address the actual $\mathrm{N}$ load in subsurface drainage, which would also depend on the water balance at different times of the growing season. Incorporating fertilizer before planting did not result in significantly different annual $\mathrm{NO}_{3}-\mathrm{N}$ concentrations from incorporating fertilizer in season (16.1 and $13.6 \mathrm{mg} \mathrm{L}^{-1}$, respectively).

Dissolved $\mathrm{P}$ concentrations in subsurface drainage were significantly greater for injected fertilizer applications than for incorporated and surface applied applications, although this analysis was limited by very small sample sizes, as was the fertilizer timing analysis (table 2). A possible reason for this difference might be that the three injected site-years were all for applications of liquid dairy manure, which may

Table 2. Corn yields $\left(\mathrm{Mg} \mathrm{ha}^{-1}\right)$, mean $\mathrm{N}$ and $\mathrm{P}$ application rates $\left(\mathrm{kg} \mathrm{ha}^{-1}\right)$, and flow-weighted mean $\mathrm{NO}_{3}-\mathrm{N}$ and $\mathrm{DRP}$ concentrations $\left(\mathrm{mg} \mathrm{L}^{-1}\right)$ associated with fertilizer application method categories in the MANAGE Drain Concentration database. Numbers in parentheses are sample size. Sample sizes are associated with fertilizer application methods, and data between columns may not be associated with the same studies. Within a column, means with the same letter are not significantly different $(\alpha=0.05)$.

\begin{tabular}{|c|c|c|c|c|c|}
\hline Fertilizer Application Method & $\begin{array}{c}\text { Corn Yield } \\
\left(\mathrm{Mg} \mathrm{ha}^{-1}\right)\end{array}$ & $\begin{array}{c}\text { N Application } \\
\text { Rate } \\
\left(\mathrm{kg} \mathrm{N} \mathrm{ha}^{-1}\right)\end{array}$ & $\begin{array}{c}\mathrm{NO}_{3}-\mathrm{N} \\
\text { Concentration } \\
\left(\mathrm{mg} \mathrm{L}^{-1}\right)\end{array}$ & $\begin{array}{c}\text { P Application } \\
\text { Rate } \\
\left(\mathrm{kg} \mathrm{P} \mathrm{ha}^{-1}\right)\end{array}$ & $\begin{array}{c}\text { DRP } \\
\text { Concentration }^{[\mathrm{b}]} \\
\left(\mathrm{mg} \mathrm{L}^{-1}\right)\end{array}$ \\
\hline Incorporated & $11.2(53) \mathrm{a}$ & $182(39) \mathrm{a}$ & $14.2(57) \mathrm{a}$ & $43(14) \mathrm{a}$ & $0.02(14) \mathrm{b}$ \\
\hline Injected & $8.3(230) b$ & $164(326) a$ & 14.1 (329) a & $40(3) \mathrm{a}$ & $0.25(3) \mathrm{a}$ \\
\hline Surface applied & $4.8(19) \mathrm{c}$ & $164(29) \mathrm{a}$ & $10.3(31) b$ & $39(18) \mathrm{a}$ & $0.02(22) b$ \\
\hline
\end{tabular}

\footnotetext{
[a] Data from $\mathrm{N}$ or $\mathrm{N}+\mathrm{P}$ nutrient sources.
}

[b] Data from N+P nutrient sources only. 
not be broadly representative. In addition, incorporated and injected fertilizers are less prone to transport from surface runoff events than surface applied P (Klatt et al., 2003).

\section{Nutrient Source}

Organic P sources (e.g., manures, litter) were applied at significantly greater rates than inorganic $\mathrm{P}$ sources $(84$ versus $27 \mathrm{~kg} \mathrm{P} \mathrm{ha}^{-1}$; fig. 4a), which was also a finding from the MANAGE Drain Load database (Christianson et al., 2016). The large application rates for organic $\mathrm{P}$ sources may be a result of manure applications calculated to supply a specific amount of $\mathrm{N}$ without considering the $\mathrm{P}$ rate. For instance, Nguyen et al. (2013) used poultry manure, known to be high in $\mathrm{P}$, to supply up to $326 \mathrm{~kg} \mathrm{~N}^{-1}$. This resulted in $\mathrm{P}$ applications as high as $472 \mathrm{~kg} \mathrm{P} \mathrm{ha}^{-1}$. Moreover, Hoover et al. (2015) identified the difficulty of meeting target P application rates because of the high variability in poultry manure nutrient content. Greater organic $\mathrm{P}$ application rates may have resulted in increased corn yield (11.1 versus $8.1 \mathrm{Mg}$ ha $^{-1}$; fig. 4b); however, this yield increase may have also resulted from other macro- or micro-nutrients found in organic fertilizer sources that are not inherently supplied with inorganic $\mathrm{P}$ sources or from other indirect improvements in soil quality, such as the potential for improved water-holding capacity. There were no significant differences in annual flowweighted DRP or arithmetic TP concentrations between organic and inorganic P sources (figs. $4 \mathrm{c}$ and $4 \mathrm{~d}$ ). Andersson et al. (2015) stated that higher P leaching from the soil profile
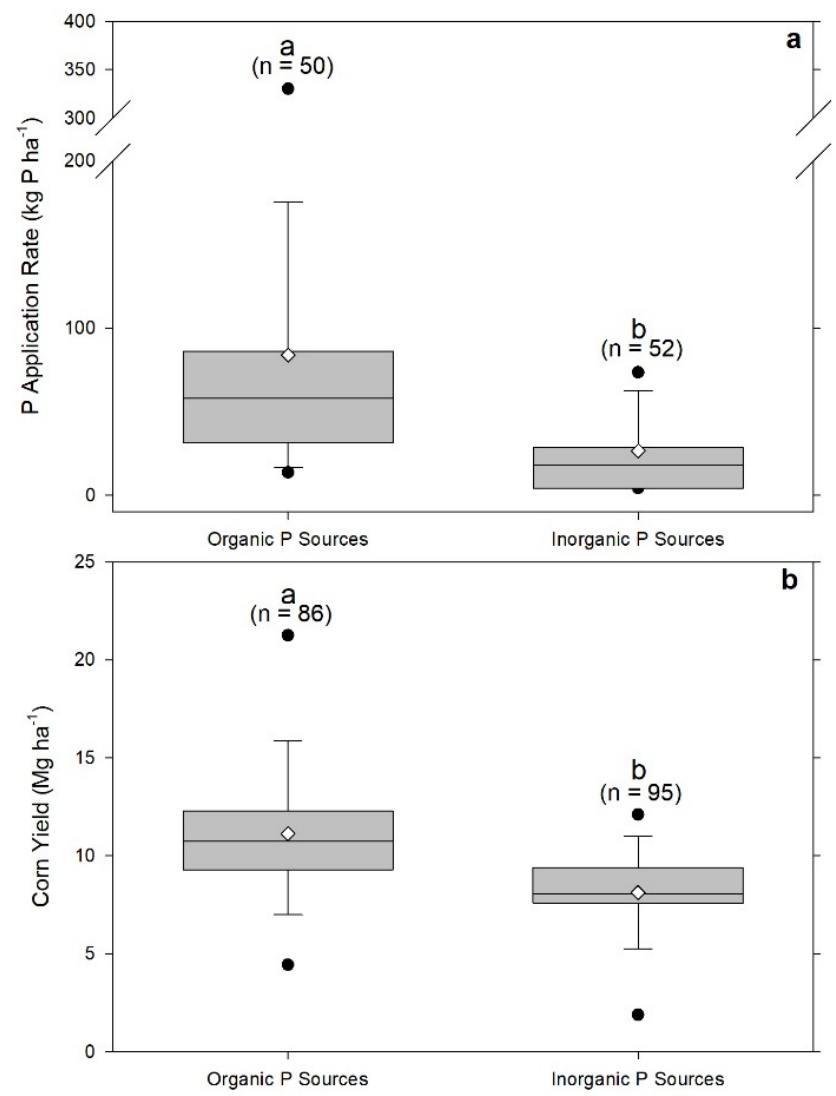

than from the topsoil may occur in some subsoils that are naturally enriched with $\mathrm{P}$ or from fields that obtain frequent inputs of manure. Therefore, these concentrations are likely confounded with the fertilizer source as well as other factors, such as fertilizer rate, timing, placement, and soil composition.

\section{TILLAGE}

Tillage practices were reported in $59 \%(n=922)$ of the total site-years and included conventional tillage (leaving $<15 \%$ residue cover; $n=591$ ), conservation tillage (leaving $>30 \%$ residue cover; $n=194)$, and no-till $(n=137)$ (Baker, 2011). Annual precipitation was not significantly different between tillage types in the database (table 3), which was not surprising because $84 \%$ of the site-years for which tillage was reported were in Iowa (Iowa's long-term annual average precipitation is $881 \mathrm{~mm}$; NOAA, 2010). However, conventional tillage had significantly greater annual drain discharge (237 mm year $\left.{ }^{-1}\right)$ than conservation tillage and no-till (154 and $176 \mathrm{~mm}$ year $^{-1}$, respectively), which was also true for the fraction of precipitation occurring as drainage $(29 \%, 19 \%$, and $20 \%$ for conventional, conservation, and no-till, respectively; table 3). Drury et al. (1993) found that greater subsurface drainage volume occurred with conventional tillage than with conservation and no-till treatments in a corn cropping system. Annual flow-weighted $\mathrm{NO}_{3}-\mathrm{N}$ concentrations were significantly higher for conservation tillage $(16.1 \mathrm{mg}$ $\left.\mathrm{L}^{-1}\right)$, followed by conventional $\left(13.8 \mathrm{mg} \mathrm{L}^{-1}\right)$ and no-till $(10.1$

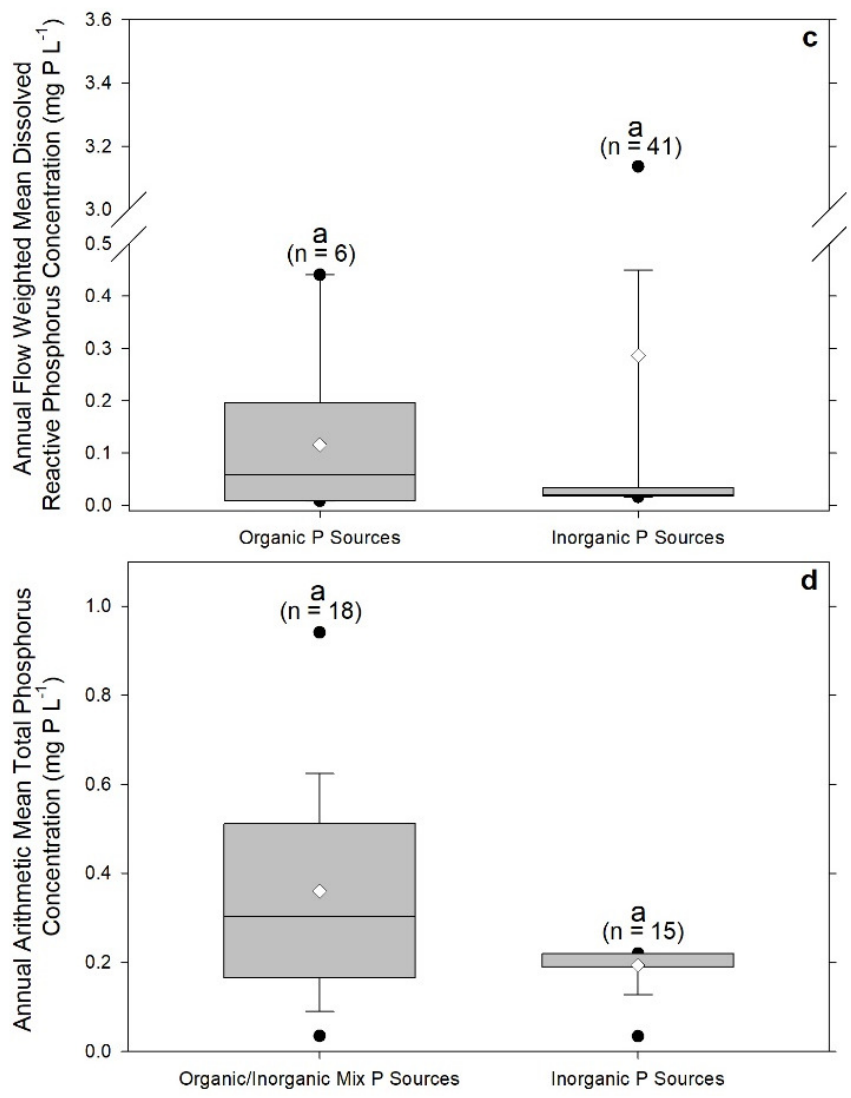

Figure 4. (a) Mean $P$ application rates $\left(\mathrm{kg} \mathrm{ha}^{-1}\right)$, (b) corn yield $\left(\mathrm{Mg} \mathrm{ha}^{-1}\right)$, (c) annual flow-weighted mean DRP concentrations $\left(\mathrm{mg} \mathrm{L}^{-1}\right)$, and $(\mathrm{d})$ annual arithmetic mean TP concentrations $\left(\mathrm{mg} \mathrm{L}^{-1}\right)$ for organic versus inorganic $P$ fertilizer sources. Means with the same letters are not significantly different $(\alpha=0.05)$. Boxes, stems, and dots represent the 25th and 75th, 10th and 90th, and 5th and 95th percentiles, respectively; the horizontal line is the median concentration, and the diamond is the mean concentration. 
Table 3. Annual precipitation $(\mathrm{mm})$, annual subsurface drainage $(\mathrm{mm})$, drainage/precipitation ratio, maximum flow rate $\left(\mathrm{m}^{3} \mathrm{~s}^{-1}\right)$, annual flowweighted mean $\mathrm{NO}_{3}-\mathrm{N}$ concentration $\left(\mathrm{mg} \mathrm{L}^{-1}\right)$, and annual flow-weighted mean DRP concentration $\left(\mathrm{mg} \mathrm{L}^{-1}\right)$ associated with tillage type in the MANAGE Drain Concentration database. Numbers in parentheses are sample size. Sample sizes are associated with tillage type, and data between columns may not be associated with the same studies. Within a column, means with the same letters are not significantly different at $\alpha=0.05$. Tillage types defined as "conventional" included tillage practices that leave $<15 \%$ residue cover, and "conservation" included tillage practices that leave $>30 \%$ residue cover.

\begin{tabular}{|c|c|c|c|c|c|c|}
\hline Tillage Type & $\begin{array}{l}\text { Precipitation } \\
\left(\mathrm{mm}^{-1} \text { year }^{-1}\right)\end{array}$ & $\begin{array}{c}\text { Drain Discharge } \\
\left(\mathrm{mm} \mathrm{year}^{-1}\right)\end{array}$ & $\begin{array}{c}\text { Drainage / } \\
\text { Precipitation } \\
\text { Ratio } \\
\end{array}$ & $\begin{array}{c}\text { Maximum } \\
\text { Flow Rate } \\
\left(\mathrm{m}^{3} \mathrm{~s}^{-1}\right)\end{array}$ & $\begin{array}{c}\text { Annual } \\
\text { Flow-Weighted } \\
\mathrm{NO}_{3}-\mathrm{N}\left(\mathrm{mg} \mathrm{L}^{-1}\right)\end{array}$ & $\begin{array}{c}\text { Annual } \\
\text { Flow-Weighted } \\
\text { DRP }\left(\mathrm{mg} \mathrm{L}^{-1}\right)\end{array}$ \\
\hline Conventional & $807(333) \mathrm{a}$ & $237(335) \mathrm{a}$ & $0.29(333) \mathrm{a}$ & $0.015(23) \mathrm{a}$ & $13.8(412) b$ & $0.20(92) \mathrm{a}$ \\
\hline Conservation & $810(126) \mathrm{a}$ & $154(152) b$ & $0.19(126) b$ & $0.007(38) b$ & 16.1 (187) a & $0.02(20) b$ \\
\hline No-till & 847 (94) a & $176(118) b$ & $0.20(94) \mathrm{b}$ & $0.012(9) \mathrm{ab}$ & $10.1(126) \mathrm{c}$ & $0.08(6) \mathrm{a}$ \\
\hline
\end{tabular}

$\left.\mathrm{mg} \mathrm{L}^{-1}\right)$. Similarly, a corn cropping system in Ontario produced greater flow-weighted $\mathrm{NO}_{3}-\mathrm{N}$ concentrations with conventional tillage than with no-till (Drury et al., 1993). A recent meta-analysis reported greater $\mathrm{NO}_{3}-\mathrm{N}$ concentrations in leachate from conventional tillage compared to no-till when the data were grouped by specific factors such as coarse and medium soil texture, wet years, fields in soybeans, and unfertilized fields, but overall the study found similar concentrations between the two tillage types, highlighting the effect of confounding factors on drainage water concentrations (Daryanto et al., 2017). There is clear variability across the literature, as Bjorneberg et al. (1996) observed greater subsurface drainage $\mathrm{NO}_{3}-\mathrm{N}$ concentrations from plots that were moldboard and chisel plowed than from ridge and no-till plots. Interactions of tillage, soil series, and soil texture undoubtedly influence drainage volume and nutrient concentrations, but unfortunately few site-years reported both tillage type and soil information, thus precluding deeper analysis. Annual flow-weighted DRP concentrations did not follow the same trend. Conventional and no-till siteyear DRP concentrations were not significantly different from each other $\left(0.20\right.$ and $0.08 \mathrm{mg} \mathrm{L}^{-1}$, respectively) but were significantly higher than conservation tillage $(0.02 \mathrm{mg}$ $\left.\mathrm{L}^{-1}\right)$ (table 3). Again, deeper analysis of the DRP results was limited by the relatively low site-year counts in the database; the limited DRP concentration site-years are a finding in themselves and call for greater understanding of $\mathrm{P}$ in drainage water.

\section{REGRESSION MODELING OF DRAINAGE NUTRIENT CONCENTRATION}

Regression analysis of the top-ranked model from the stepwise selection process indicated that the likely factors

Table 4. Significant parameter estimates from the stepwise regression model of annual $\mathrm{NO}_{3}-\mathrm{N}$ concentrations (both flow-weighted and arithmetic annual means) using corn-only site-years in the MANAGE Drain Concentration database $(n=254)$; $p$-values were considered significant at $\alpha=0.05$. Partial $R^{2}$ values for each parameter sum to the total $R^{2}$ of 0.59 . Variance inflation factors (VIF) of $<10$ suggested that there were no multicollinearity issues.

\begin{tabular}{|c|c|c|c|}
\hline Parameter & $\begin{array}{c}\text { Parameter } \\
\text { Estimate }\end{array}$ & $\begin{array}{c}\text { Partial R2 } \\
(\text { total }=0.59)\end{array}$ & VIF \\
\hline Intercept & 5.54955 & NA & 0 \\
\hline Nitrogen application rate ${ }^{[a]}$ & 0.0002 & 0.302 & 1.16 \\
\hline Fertilizer application timing & 3.3 & 0.140 & 1.08 \\
\hline Tillage & 4.1 & 0.090 & 5.48 \\
\hline Tillage $\times$ split nitrogen & 2.3 & 0.031 & 1.86 \\
\hline Tillage $\times$ Annual drain discharge $\mathrm{e}^{[\mathrm{b}]}$ & -0.02 & 0.028 & 4.48 \\
\hline Fertilizer method of application & 2.9 & 0.0001 & 1.28 \\
\hline
\end{tabular}

[a] Quadratic portion of nitrogen application rate: $\left(\mathrm{kg} \mathrm{N} \mathrm{ha}^{-1}\right)^{2}$.

[b] Annual drainage discharge in $\mathrm{mm}$ year ${ }^{-1}$. contributing to the variability of annual $\mathrm{NO}_{3}-\mathrm{N}$ concentrations across the corn site-years included $\mathrm{N}$ application and tillage (table 4). The following model based on both flowweighted and arithmetic means $(n=254)$ had an overall $\mathrm{R}^{2}$ of 0.59:

$$
\begin{aligned}
\mathrm{NO}_{3}-\mathrm{N}= & 5.54955+0.000186\left(X_{i 1}\right)^{2}+3.2862 X_{i 2} \\
& +4.09706 X_{i 3}+2.25987 X_{i 4} \\
& -0.01634 X_{i 5}+2.88133 X_{i 6}
\end{aligned}
$$

where $X_{i 1}=\mathrm{N}$ application rate $\left(\mathrm{kg} \mathrm{ha}^{-1}\right), X_{i 2}=1$ if out of season or pre-plant fertilization timing and 0 if otherwise, $X_{i 3}=$ 1 if conventionally tilled and 0 if otherwise, $X_{i 4}=1$ if conventionally tilled with a split-N application and 0 if otherwise, $X_{i 5}=$ drain discharge $\left(\mathrm{mm} \mathrm{year}^{-1}\right)$ if conventionally tilled and 0 if not conventionally tilled, and $X_{i 6}=1$ if fertilizer was injected and 0 if otherwise. While the model explained a relatively large amount of the variation in the data (table 4 and fig. 5) based on partial $\mathrm{R}^{2}$ values, the square of the $\mathrm{N}$ application rate $\left(\mathrm{kg} \mathrm{N} \mathrm{ha}^{-1}\right)$ had the greatest effect on annual mean $\mathrm{NO}_{3}-\mathrm{N}$ concentrations in corn site-years, followed by fertilizer timing, tillage type, the interaction between tillage and split-N application, the interaction between tillage and annual drain discharge, and the method of fertilizer application (table 4). The majority of all data points used for the model were above the USEPA MCL for $\mathrm{NO}_{3}-\mathrm{N}$ in drinking water. The variance inflation factors (VIF) of

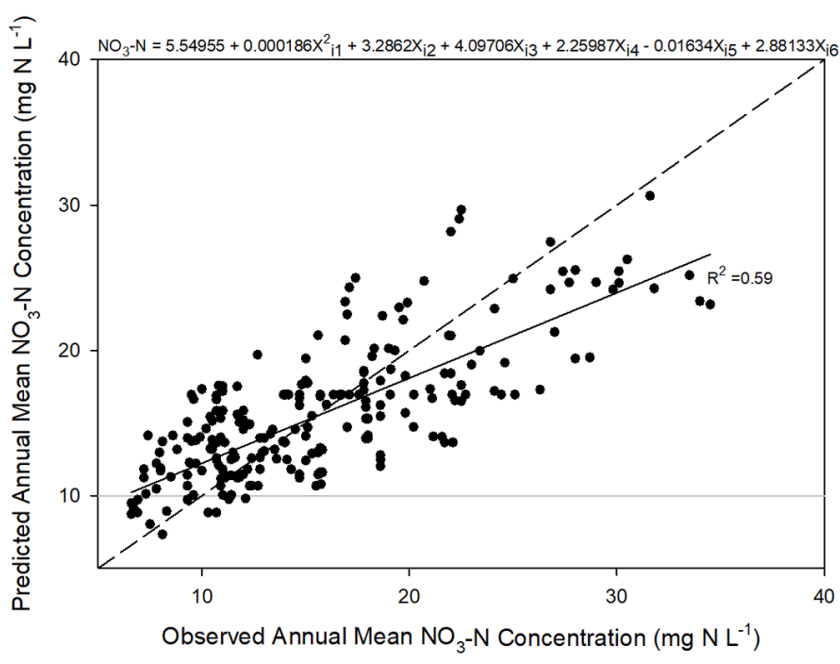

Figure 5. Comparison of regression model predicted versus observed annual $\mathrm{NO}_{3}-\mathrm{N}$ mean concentrations using corn site-years only in the MANAGE Drain Concentration database. The horizontal line represents the USEPA maximum contaminant load (MCL) of $10 \mathrm{mg} \mathrm{N} \mathrm{L}^{-1}$ for drinking water, the solid diagonal line is the modeled regression, the dashed diagonal line is the $1: 1$ line, and subscript $i$ represents a particular observation in the database. 
$<10$ suggest that there were no multicollinearity issues between factors (i.e., multiple predictor variables were not explaining the same variability within the data, resulting in an overfitted model).

The most significant results from the model corroborated other results in that increased $\mathrm{N}$ application rate (fig. $3 \mathrm{~b}$ ) and out of season and pre-plant fertilizer timings (table 1) increased annual $\mathrm{NO}_{3}-\mathrm{N}$ concentrations. According to the model, split- $\mathrm{N}$ application increased annual $\mathrm{NO}_{3}-\mathrm{N}$ concentrations but only in conventionally tilled corn. This may be explained by the ability of conventional tillage to increase $\mathrm{N}$ mineralization rates (Dinnes et al., 2002) coupled with the reduction of $\mathrm{C}$ to $\mathrm{N}$ ratios after each $\mathrm{N}$ application. According to the model, larger drain discharges decreased $\mathrm{NO}_{3}-\mathrm{N}$ concentrations in site-years where conventional tillage was used (table 4), possibly due to dilution effects and the relatively poorer water retention of conventionally tilled soils (Dinnes et al., 2002).

Regression analysis for annual DRP concentrations was based on fewer observations ( $n=47$; both flow-weighted and arithmetic annual means), resulting in less robust conclusions. However, the overall model $\mathrm{R}^{2}$ was 0.94 :

$$
\begin{aligned}
\ln (\mathrm{DRP}) & =-0.47402-3.24351 X_{i 1}+2.65095 X_{i 2} \\
& -0.00164 X_{i 3}
\end{aligned}
$$

where $X_{i 1}=1$ if out of season or pre-plant fertilization timing and 0 if otherwise, $X_{i 2}=1$ if fertilizer was surface applied and 0 if otherwise, and $X_{i 3}=$ annual drain discharge ( $\mathrm{mm}$ year $^{-1}$ ). Fertilizer timing was most closely correlated with annual DRP concentrations in corn site-years, followed by fertilizer method of application and annual drainage discharge (table 5). Earlier analysis of fertilizer timing effects on DRP concentrations was significant (i.e., table 1) but suffered from low sample sizes. Considering sample sizes of at least ten site-years or more, out of season applications had lower annual DRP concentrations compared to pre-plant applications (table 1). This was reflected in the negative slope for fertilizer timing in the model (-3.24 in eq. 2). The importance of the different nutrient application timings for the $\mathrm{NO}_{3}-\mathrm{N}$ versus the DRP models was notable. Application of $\mathrm{N}$ before planting (e.g., out of season and pre-plant) extends time in which applied $\mathrm{N}$ can be translocated out of the root zone, resulting in elevated drainage $\mathrm{N}$ concentrations. Conversely, pre-plant or within-spring $\mathrm{P}$ applications are more susceptible to intense precipitation events, which may exacerbate $\mathrm{P}$ movement through the soil profile. Fall or early spring $\mathrm{P}$ applications may be more susceptible to runoff events (snowmelt and early spring precipitation) rather than

Table 5. Significant parameter estimates from the stepwise regression model of annual DRP concentrations (both flow-weighted and arithmetic annual means) using corn-only site-years in the MANAGE Drain Concentration database $(n=47)$; $p$-values were considered significant at $\alpha=0.05$. Partial $R^{2}$ values for each parameter sum to the total $R^{2}$ of 0.94 . Variance inflation factors (VIF) of $<10$ suggested that there were no multicollinearity issues.

\begin{tabular}{cccc}
\hline & $\begin{array}{c}\text { Parameter } \\
\text { Estimate }\end{array}$ & $\begin{array}{c}\text { Partial R } \\
\text { (total }=0.94)\end{array}$ & VIF \\
\hline Parameter & -0.5 & $\mathrm{NA}$ & 0 \\
Intercept & -3.2 & 0.600 & 1.08 \\
Fertilizer application timing & 2.7 & 0.226 & 1.28 \\
Fertilizer method of application & -0.002 & 0.115 & 1.86 \\
\hline Annual drain discharge $\left(\right.$ mm year $\left.^{-1}\right)$ & & &
\end{tabular}

drainage events, especially if the $\mathrm{P}$ is on the soil surface. For example, Ontkean et al. (2005) found nearly double the flow-weighted mean concentration and load of both total $\mathrm{P}$ and total dissolved $\mathrm{P}$ in snowmelt runoff compared to growing season runoff across watersheds largely used for annual crop agriculture in Alberta, Canada.

The model reflected an increase in DRP concentration with surface application of nutrients compared to incorporated or injected applications, contradicting the previous analysis of fertilizer application methods, which showed that injected applications contributed the largest DRP concentrations (table 2). This contradiction may be due to the few injected site-years included in the model $(n=3)$ compared to the incorporated method of application $(n=14)$, which had the lowest annual DRP concentration (table 2). An increase in drain discharge showed a slight decrease in annual DRP concentration within the model (slope $=-0.002$ in eq. 2 ), possibly reflecting dilution of the DRP concentrations within the observed drainage discharge values.

\section{SUMMARY AND CONCLUSIONS}

This analysis of drainage nutrient concentration data in the MANAGE Drain Concentration database further established several key links between in-field management practices and the fate of nutrients in agricultural systems. Cropping system showed an impact on annual drainage $\mathrm{NO}_{3}-\mathrm{N}$ concentrations, with annual crop site-years averaging greater than $10 \mathrm{mg} \mathrm{L}^{-1}$, which is the USEPA-established MCL for drinking water, while perennial crop site-years averaged lower concentrations. Conversely, annual flow-weighted DRP concentrations for corn, soybean, and alfalfa site-years were not significantly different from each other, which indicated that cropping system was a relatively less important factor for the movement of DRP to subsurface drainage systems compared to the movement of $\mathrm{NO}_{3}-\mathrm{N}$.

Increasing $\mathrm{N}$ application rates to corn increased yields and generally increased $\mathrm{NO}_{3}-\mathrm{N}$ concentrations in subsurface drainage, a finding that was corroborated with modeling across the database. From 29 initial parameters in the stepwise regression model, $\mathrm{N}$ application rate had the greatest effect on $\mathrm{NO}_{3}-\mathrm{N}$ concentration in corn site-years, followed by fertilizer timing. However, $\mathrm{N}$ rates well below the typical on-farm practice or university recommendations for corn (i.e., rates less than $74 \mathrm{~kg} \mathrm{ha}^{-1}$ ) did not result in significantly lower $\mathrm{NO}_{3}-\mathrm{N}$ concentrations compared to higher $\mathrm{N}$ rate categories, excluding the $>224 \mathrm{~kg} \mathrm{ha}^{-1}$ category. Increasing $\mathrm{N}$ application rates to between 150 and $224 \mathrm{~kg} \mathrm{ha}^{-1}$ (a typical range for Midwestern corn production) increased corn yields, and additional $\mathrm{N}$ above that rate did not increase yields. These results emphasize the importance of applying adequate $\mathrm{N}$ (e.g., 150 to $224 \mathrm{~kg} \mathrm{ha}^{-1}$ ) to produce reasonable yields and not applying excess $\mathrm{N}$ (e.g., $>224 \mathrm{~kg} \mathrm{ha}^{-1}$ ), which leaves much of the applied $\mathrm{N}$ available for loss.

In terms of $\mathrm{N}$ application timing for corn, while the two $\mathrm{N}$ timings that were most out of sync with crop growth (i.e., out of season and pre-plant applications) resulted in the greatest $\mathrm{NO}_{3}-\mathrm{N}$ concentrations in subsurface drainage, these two timings also had the greatest $\mathrm{N}$ application rates across 
the database, which confounded this assessment. There was no significant difference in $\mathrm{NO}_{3}-\mathrm{N}$ concentrations from siteyears with split-N applications versus site-years without split-N applications. Given the increasing emphasis on split$\mathrm{N}$ applications for meeting nutrient loss reduction goals, additional field studies are needed to determine their effectiveness as a recommended $4 \mathrm{R}$ practice.

Stepwise regression models indicated that the timing of $\mathrm{P}$ application was the most significant $4 \mathrm{R}$ factor for DRP drainage losses during corn site-years, although this analysis was limited by the small sample size $(n=47)$. This limitation emphasizes the need to bolster research efforts on transport of $\mathrm{P}$ in subsurface agricultural drainage, especially in the face of increasing P-related water quality impairments. The MANAGE Drain Concentration database is publicly available (https://www.ars.usda.gov/plains-area/temple-tx/grassland-soil-and-water-research-laboratory/docs/manage-nutrient-loss-database/) and should continue to be used by the science community, state and federal agencies, and conservation and agricultural organizations to better understand and mitigate nutrient-related water quality issues in agriculture.

\section{ACKNOWLEDGEMENTS}

The authors gratefully acknowledgments the Illinois Nutrient Research and Education Council (NREC) for their support of this work.

\section{REFERENCES}

Andersson, H., Bergstrom, L., Ulen, B., Djodjic, F., \& Kirchmann, H. (2015). The role of subsoil as a source or sink for phosphorus leaching. J. Environ. Qual., 44(2), 535-544. https://doi.org/10.2134/jeq2014.04.0186

Baker, N. T. (2011). Tillage practices in the conterminous United States, 1989-2004: Datasets aggregated by watershed. National Water-Quality Assessment Program prepared in cooperation with the Conservation Technology Information Center Data Series 573. USGS. https://doi.org/10.3133/ds573

Ball Coelho, B., Lapen, D., Murray, R., Topp, E., Bruin, A., \& Khan, B. (2012). Nitrogen loading to offsite waters from liquid swine manure application under different drainage and tillage practices. Agric. Water Mgmt., 104, 40-50. https://doi.org/10.1016/j.agwat.2011.11.014

Bjorneberg, D. L., Kanwar, R. S., \& Melvin, S. W. (1996). Seasonal changes in flow and nitrate-N loss from subsurface drains. Trans. ASAE, 39(3), 961-967. https://doi.org/10.13031/2013.27582

Bolton, E. F., Aylesworth, J. W., \& Hore, F. R. (1970). Nutrient losses through tile drains under three cropping systems and two fertility levels on a Brookston clay soil. Canadian J. Soil Sci., 50(3), 275-279. https://doi.org/10.4141/cjss70-038

Burnham, K. P., \& Anderson, D. R. (2002). Model selection and multimodel inference: A practical information-theoretic approach (2nd. ed.). New York, NY: Springer-Verlag.

Christianson, L. E., \& Harmel, R. D. (2015a). The MANAGE drain load database: Review and compilation of more than fifty years of North American drainage nutrient studies. Agric. Water Mgmt., 159, 277-289. https://doi.org/10.1016/j.agwat.2015.06.021

Christianson, L. E., \& Harmel, R. D. (2015b). 4R water quality impacts: An assessment and synthesis of forty years of drainage nitrogen losses. J. Environ. Qual., 44(6), 1852-1860. https://doi.org/10.2134/jeq2015.03.0170
Christianson, L. E., Harmel, R. D., Smith, D., Williams, M. R., \& King, K. (2016). Assessment and synthesis of 50 years of published drainage phosphorus losses. J. Environ. Qual., 45(5), 1467-1477. https://doi.org/10.2134/jeq2015.12.0593

Daigh, A. L., Zhou, X., Helmers, M. J., Pederson, C. H., Horton, R., Jarchow, M., \& Liebman, M. (2015). Subsurface drainage nitrate and total reactive phosphorus losses in bioenergy-based prairies and corn systems. J. Environ. Qual., 44(5), 1638-1646. https://doi.org/10.2134/jeq2015.02.0080

Daryanto, S., Wang, L., \& Jacinthe, P.-A. (2017). Impacts of notillage management on nitrate loss from corn, soybean, and wheat cultivation: A meta-analysis. Sci. Rep., 7(1), 12117. https://doi.org/10.1038/s41598-017-12383-7

Diaz, R. J., \& Rosenberg, R. (2008). Spreading dead zones and consequences for marine ecosystems. Science, 321(5891), 926929. https://doi.org/10.1126/science.1156401

Dinnes, D. L., Karlen, D. L., Jaynes, D. B., Kaspar, T. C., Hatfield, J. L., Colvin, T. S., \& Cambardella, C. A. (2002). Nitrogen management strategies to reduce nitrate leaching in tile-drained midwestern soils. Agron. J., 94(1), 153-171. https://doi.org/10.2134/agronj2002.1530

Drury, C. F., Findlay, W. I., Gaynor, J. D., \& McKenney, D. J. (1993). Influence of tillage on nitrate loss in surface runoff and tile drainage. SSSA J., 57(3), 797-802. https://doi.org/10.2136/sssaj1993.03615995005700030028x

Eagle, A. J., Christianson, L. E., Cook, R. L., Harmel, R. D., Miguez, F. E., Qian, S. S., \& Ruiz Diaz, D. A. (2017a). Metaanalysis constrained by data: Recommendations to improve relevance of nutrient management research. Agron. J., 109(6), 2441-2449. https://doi.org/10.2134/agronj2017.04.0215

Eagle, A. J., Olander, L. P., Locklier, K. L., Heffernan, J. B., \& Bernhardt, E. S. (2017b). Fertilizer management and environmental factors drive $\mathrm{N}_{2} \mathrm{O}$ and $\mathrm{NO}_{3}$ losses in corn: A meta-analysis. SSSA J., 81(5), 1191-1202. https://doi.org/10.2136/sssaj2016.09.0281

Fertilizer Institute. (2015). What are the 4Rs? Washington, DC: The Fertilizer Institute. Retrieved from http://www.nutrientstewardship.com/4rs

Galloway, J. N., Aber, J. D., Erisman, J. W., Seitzinger, S. P., Howarth, R. W., Cowling, E. B., \& Cosby, B. J. (2003). The nitrogen cascade. Bioscience, 53(4), 341-356. https://doi.org/10.1641/0006-3568(2003)053[0341:tnc]2.0.co;2

Gentry, L. E., David, M. B., Below, F. E., Royer, T. V., \& McIsaac, G. F. (2009). Nitrogen mass balance of a tile-drained agricultural watershed in east-central Illinois. J. Environ. Qual., 38(5), 18411847. https://doi.org/10.2134/jeq2008.0406

Gentry, L. E., David, M. B., Smith, K. M., \& Kovacic, D. A. (1998). Nitrogen cycling and tile drainage nitrate loss in a corn/soybean watershed. Agric. Ecosyst. Environ., 68(1), 85-97. https://doi.org/10.1016/S0167-8809(97)00139-4

Harmel, D. R., Christianson, L. E., McBroom, M. W., Smith, D. R., \& Higgs, K. D. (2016). Expansion of the MANAGE database with forest and drainage studies. JAWRA, 52(5), 1275-1279. https://doi.org/10.1111/1752-1688.12438

Harmel, D., Potter, S., Casebolt, P., Reckhow, K., Green, C., \& Haney, R. (2006). Compilation of measured nutrient load data for agricultural land uses in the United States. JAWRA, 42(5), 1163-1178. https://doi.org/10.1111/j.1752-1688.2006.tb05292.x

Harmel, D., Qian, S., Reckhow, K., \& Casebolt, P. (2008). The MANAGE database: Nutrient load and site characteristic updates and runoff concentration data. J. Environ. Qual., 37(6), 2403-2406. https://doi.org/10.2134/jeq2008.0079

Harmel, R. D., Christianson, L. E., \& McBroom, M. (2017). Measured annual nutrient loads from agricultural environments (MANAGE) database. Washington, DC: National Agricultural Library. https://doi.org/10.15482/USDA.ADC/1372907 
Harrell Jr., F. E. (2015). Regression modeling strategies: With applications to linear models, logistic and ordinal regression, and survival analysis (2nd. ed.). New York, NY: Springer. https://doi.org/10.1007/978-3-319-19425-7

Helmers, M. J., Zhou, X., Baker, J. L., Melvin, S. W., \& Lemke, D. W. (2012). Nitrogen loss on tile-drained Mollisols as affected by nitrogen application rate under continuous corn and cornsoybean rotation systems. Canadian J. Soil Sci., 92(3), 493-499. https://doi.org/10.4141/cjss2010-043

Hertzberger, A., Pittelkow, C. M., Harmel, R. D., \& Christianson, L. E. (2019). The MANAGE drain concentration database: A new tool compiling North American drainage nutrient concentrations. Agric. Water Mgmt., 216, 113-117. https://doi.org/10.1016/j.agwat.2019.01.021

Hoover, N. L., Kanwar, R., Soupir, M. L., \& Pederson, C. (2015). Effects of poultry manure application on phosphorus in soil and tile drain water under a corn-soybean rotation. Water Air Soil Pollut., 226, 138. https://doi.org/10.1007/s1 1270-015-2403-9

Jaynes, D. B., \& Colvin, T. S. (2006). Corn yield and nitrate loss in subsurface drainage from midseason nitrogen fertilizer application. Agron. J., 98(6), 1479-1487. https://doi.org/10.2134/agronj2006.0046

Kanwar, R. S., Baker, J. L., \& Baker, D. G. (1988). Tillage and split $\mathrm{N}$-fertilization effects on subsurface drainage water quality and crop yields. Trans. ASAE, 31(2), 453-461. https://doi.org/10.13031/2013.30730

King, K. W., Williams, M. R., Macrae, M. L., Fausey, N. R., Frankenberger, J., Smith, D. R., ... Brown, L. C. (2015). Phosphorus transport in agricultural subsurface drainage: A review. J. Environ. Qual., 44(2), 467-485. https://doi.org/10.2134/jeq2014.04.0163

Klatt, J. G., Mallarino, A. P., Downing, J. A., Kopaska, J. A., \& Wittry, D. J. (2003). Soil phosphorus, management practices, and their relationship to phosphorus delivery in the Iowa Clear Lake agricultural watershed. J. Environ. Qual., 32(6), 21402149. https://doi.org/10.2134/jeq2003.2140

Lawlor, P. A., Helmers, M. J., Baker, J. L., Melvin, S. W., \& Lemke, D. W. (2008). Nitrogen application rate effect on nitratenitrogen concentration and loss in subsurface drainage for a corn-soybean rotation. Trans. ASABE, 51(1), 83-94. https://doi.org/10.13031/2013.24229

Lawlor, P. A., Helmers, M. J., Baker, J. L., Melvin, S. W., \& Lemke, D. W. (2011). Comparison of liquid swine manure and aqua-ammonia nitrogen application timing on subsurface drainage water quality in Iowa. Trans. ASABE, 54(3), 973-981. https://doi.org/10.13031/2013.37121

McLellan, E. L., Cassman, K. G., Eagle, A. J., Woodbury, P. B., Sela, S., Tonitto, C., ... van Es, H. M. (2018). The nitrogen balancing act: Tracking the environmental performance of food production. BioScience, 68(3), 194-203.

Mengel, D. B., Nelson, D. W., \& Huber, D. M. (1982). Placement of nitrogen fertilizers for no-till and conventional till corn. Agron. J., 74(3), 515-518. https://doi.org/10.2134/agronj1982.00021962007400030026x

Mitchell, J. K., McIsaac, G. F., Walker, S. E., \& Hirschi, M. C. (2000). Nitrate in river and subsurface drainage flows from an east central Illinois watershed. Trans. ASAE, 43(2), 337-342. https://doi.org/10.13031/2013.2709

Nguyen, H. Q., Kanwar, R. S., Hoover, N. L., Dixon, P., Hobbs, J., Pederson, C., \& Soupir, M. L. (2013). Long-term effects of poultry manure application on nitrate leaching in tile drain water. Trans. ASABE, 56(1), 91-101. https://doi.org/10.13031/2013.42593

NOAA. (2010). Climate data online. Ashville, NC: National Oceanic and Atmospheric Administration. Retrieved from https://www.ncdc.noaa.gov/cdo-web/datatools/normals

Ontkean, G. R., Chanasyk, D. S., \& Bennett, D. R. (2005). Snowmelt and growing season phosphorus flux in an agricultural watershed in south-central Alberta, Canada. Water Qual. Res. J., 40(4), 402-417. https://doi.org/10.2166/wqrj.2005.044

Randall, G. W., Huggins, D. R., Russelle, M. P., Fuchs, D. J., Nelson, W. W., \& Anderson, J. L. (1997). Nitrate losses through subsurface tile drainage in conservation reserve program, alfalfa, and row crop systems. J. Environ. Qual., 26(5), 1240-1247. https://doi.org/10.2134/jeq1997.00472425002600050007x

Schindler, D. W., Hecky, R. E., Findlay, D. L., Stainton, M. P., Parker, B. R., Paterson, M. J., ... Kasian, S. E. (2008). Eutrophication of lakes cannot be controlled by reducing nitrogen input: Results of a 37-year whole-ecosystem experiment. Proc. Natl. Acad. Sci., 105(32), 11254-11258. https://doi.org/10.1073/pnas.0805108105

Tomer, M. D., \& Liebman, M. (2014). Nutrients in soil water under three rotational cropping systems, Iowa, USA. Agric. Ecosyst. Environ., 186, 105-114. https://doi.org/10.1016/j.agee.2014.01.025

USEPA. (2009). National primary drinking water regulations. EPA 816-F-09-004. Washington, DC: U.S. Environmental Protection Agency.

Vetsch, J. A., \& Randall, G. W. (2000). Enhancing no-tillage systems for corn with starter fertilizers, row cleaners, and nitrogen placement methods. Agron. J., 92(2), 309-315. https://doi.org/10.2134/agronj2000.922309x

Zhang, T. Q., Tan, C. S., Zheng, Z. M., Welacky, T. W., \& Reynolds, W. D. (2015). Impacts of soil conditioners and water table management on phosphorus loss in tile drainage from a clay loam soil. J. Environ. Qual., 44(2), 572-584. https://doi.org/10.2134/jeq2014.04.0154 